Article

\title{
Strengthening the Role of Academic Institutions and Innovation Brokers in Agri-Food Innovation: Towards Hybridisation in Cross-Border Cooperation
}

\author{
Marina Knickel $^{1, *(\mathbb{D} \text {, Sabine Neuberger }}{ }^{2}\left(\mathbb{D}\right.$, Laurens Klerkx ${ }^{3}$, Karlheinz Knickel ${ }^{4}$, Gianluca Brunori ${ }^{1}$ (D) \\ and Helmut Saatkamp ${ }^{2}$ \\ 1 Department of Agriculture, Food and Environment, University of Pisa, 56124 Pisa, Italy; \\ gianluca.brunori@unipi.it \\ 2 Business Economics Group, Wageningen University, 6706 KN Wageningen, The Netherlands; \\ sabine.neuberger@wur.nl (S.N.); helmut.saatkamp@wur.nl (H.S.) \\ 3 Knowledge, Technology and Innovation Group, Wageningen University, \\ 6706 KN Wageningen, The Netherlands; laurens.klerkx@wur.nl \\ 4 HELSUS-Helsinki Institute of Sustainability Science, University of Helsinki, 00014 Helsinki, Finland; \\ karlheinz.knickel@helsinki.fi \\ * Correspondence: marina.kobzeva@phd.unipi.it
}

Citation: Knickel, M.; Neuberger, S.; Klerkx, L.; Knickel, K.; Brunori, G.; Saatkamp, H. Strengthening the Role of Academic Institutions and Innovation Brokers in Agri-Food Innovation: Towards Hybridisation in Cross-Border Cooperation. Sustainability 2021, 13, 4899. https:// doi.org/10.3390/su13094899

\section{Academic Editor: Joanna}

Kurowska-Pysz, Rui Alexandre Castanho and Luís Carlos Loures

Received: 28 March 2021

Accepted: 21 April 2021

Published: 27 April 2021

Publisher's Note: MDPI stays neutral with regard to jurisdictional claims in published maps and institutional affiliations.

Copyright: (c) 2021 by the authors. Licensee MDPI, Basel, Switzerland. This article is an open access article distributed under the terms and conditions of the Creative Commons Attribution (CC BY) license (https:// creativecommons.org/licenses/by/ $4.0 /)$.

\begin{abstract}
Existing research suggests that regions can develop their long-term competitive advantage through well-functioning interregional innovation cooperation. In this article, we use the example of innovation in small and medium-sized agri-food enterprises (SMEs) to scrutinise and compare regional innovation approaches on each side of the Dutch-German border and explore how they can converge into a cross-border innovation space. Particular attention is paid to the role of academic institutions and innovation brokers in creating a common innovation space. We explore how differences between two cross-border regions can be harnessed to enhance the impact of innovation, and how this may lead to what we describe as hybridisation effects. In the empirical analysis, we apply the concept of hybridisation to a cross-border innovation space, something that, as far as we are aware, has not been done before. We empirically ground the concepts of a cross-border innovation space and hybridisation and illustrate how relative regional strengths can lead to hybridisation effects. We conclude that differences in economic structures, institutional set-ups, visions and identities inherent in cross-border spaces are not only hindrances, but also opportunities, and we highlight the importance of these complementary strengths and the potential for their strategic use by regional innovation actors. Our findings are highly relevant for the further development of the Interreg Europe programme and the implementation of the EU's Territorial Agenda 2030.
\end{abstract}

Keywords: proximity; academic institutions; innovation brokers; agri-food; innovation space; hybridisation; SMEs; cross-border; Interreg; Euregio Rhein-Waal

\section{Introduction}

Regional diversity and cross-border cooperation are recognised as assets in the European Union (EU) [1]. The establishment of the emblematic Interreg Europe framework programme that celebrated its thirty years' anniversary last year is one of the main expressions of the importance placed by EU institutions on cross-border cooperation (more about the programme and its impacts: https://www.interregeurope.eu/, accessed on 11 March 2021). Interreg Europe brings together partners from border regions to learn from each other and address common challenges. Interreg focusses on four areas: regional development policy, research, innovation and SME competitiveness [2]. Both regional and European actors support the programme recognising the strategic potential of cross-border cooperation for boosting regional economies. They believe that regions can develop their 
long-term competitive advantage through well-functioning interregional innovation-driven cooperation [2-5].

Previous research on regional innovation systems (RIS) used the concept of proximity to examine its impact on regions' capacity to achieve competitive advantages through knowledge creation, interactive learning and innovation [6-9]. Geographical proximity, or the physical distance between the location of innovation actors, is central in the RIS approach and it plays a particular role in the exchange of tacit knowledge $[7,8,10]$. However, mere geographical proximity of two regions is not sufficient for interactive learning, innovation [7], and cross-border cooperation to occur [3]. Other dimensions of proximity, such as cognitive and institutional, have been deemed decisive [7,8]. More importantly, they are able to emerge independently from geographical proximity $[3,11,12]$.

The insights obtained from RIS and proximity studies were picked up by researchers working on cross-border cooperation issues [3-5,13]. These studies aimed at understanding how individual border regions can more systematically benefit from cross-border cooperation. One common denominator is that the creation of a cross-border innovation space requires factoring in contextual specificities (often highly political but also economic, sociocultural etc.), negotiating them and managing tensions $[3,4,14]$, as well as reducing border effects by promoting business, academic and other interactions across the border [15].

Kraeger et al. (2010) argue that one of the most inspiring scenarios is when the complementary strengths of regions lead to synergies "combin[ing] the best of different worlds", which can increase regional competitiveness on both sides of a border [16]. This is precisely what the hybridisation concept embodies: acknowledging mutual differences in economic, institutional and social structures, knowledge and technological capacity, political visions and cultural identities, and valorising them $[3,4,14,17,18]$. The concept itself is not new but by now it has been mostly applied in the context of public service provision, in public administration research in relation to public-private mixes, and in organisational theory in terms of combinations of coordination mechanisms (e.g., markets and networks). Kraeger et al. (2010) claim that hybridisation can be defined at different levels: organisations, networks or systems. However, this concept has been vigorously debated over a long time, which initially resulted in polarised views on its use both theoretically and empirically. Even though there is still a lack of a uniform conceptualisation and no large-scale quantitative studies to date, recent empirical evidence indicates its significance and allows more balanced assessments of its application [16]. In this paper, we focus on, what was termed by Rago and Venturi (2015) [19], a positive interpretation of hybridisation.

The concept of hybridisation has hardly been applied to cross-border innovation contexts nor has its strategic value been recognised. The only exception is Sohn [14,18], who sees cross-border spaces as "a locus of hybridisation." He acknowledges hindering effects of a border but still considers it an opportunity, provided that individual differences are valorised, frictions are reconciled, and mutual learning is recognised $[14,18,20]$. To illustrate how the concept can work in practice, Sohn refers to the trinational Euro-district of Basel "where the long-term confrontation of national differences has resulted in ... new ways of doing and thinking cross-border spatial planning and development" [14]. This is where this article aims to make its contribution by filling this gap in knowledge and empirically analysing whether and how hybridisation works out in a cross-border region.

The empirical analysis presented in this article focusses on the Dutch-German crossborder region Euregio Rhein-Waal, and on the role of academic institutions and innovation brokers in supporting innovation in agri-food SMEs. Both innovation and SMEs play a pivotal role in regional development and can substantially benefit from hybridisation. SMEs are widely acknowledged as those driving regional economic development through innovation and employment creation [21]. However, while SMEs are commonly perceived as agile, innovative and adaptive to rapidly changing markets and demands, they tend to lack necessary resources and capacity to innovate solely on their own [22,23]. SMEs often resort to other businesses, academic institutions and innovation brokers [24-28] to 
compensate for insufficient internal resources and knowledge [29,30]. This also holds true for a cross-border context [31-33].

In relation to our aim, the analysis was guided by three research questions:

(1) What are the similarities and differences between the two regions in how academic institutions and innovation brokers support innovation in agri-food SMEs?

(2) What are the relative strengths of each of the two regions in innovation-driven cooperation?

(3) What traits of a cross-border innovation space are already present in the cross-border region and how can hybridisation effects be fostered?

The article comprises six sections. After this introduction, we present a conceptual framework for the analysis that builds on three complementary concepts. Section 3 illustrates the methodology of the empirical research and introduces some basic characteristics of the two studied regions with a focus on research- and innovation-related activities. Section 4 details a comparative analysis grounded on the conceptual framework where similarities and differences between the two regions, as well as relative strengths of each of the regions are distilled. This section is concluded with the implications of these findings for a cross-border innovation space. In Section 5, main findings are summarised and discussed along the three research questions posed. Section 6 concludes the article depicting the significance of the study, its limitations and suggestions for further research.

\section{Conceptual Framework}

Building on the above, we use three complementary concepts to frame this research and provide a lens for the analysis:

- Innovation space (including the function of academic institutions and innovation brokers);

- Proximity;

- Hybridisation.

This section is structured along these three concepts.

Durand argues that social, economic, political and cultural relations within a space shape what it embodies [15]. Translating this to innovation space, McKelvey (2016) refers to the "geographical context, which affects innovation through a process of interaction of firms spanning industry as well as the regional/national institutional setting" [34]. Other authors such as Caccamo (2020) stress that innovation spaces are, inter alia, meant to bring various actors together to develop new products and processes [35]. However, what does the concept of innovation space mean in a cross-border context?

Up to now only Lundquist and Trippl and van den Broek attempted to conceptualise what a cross-border innovation space is [3,4,13,31-33]. To conceptualise a cross-border innovation space in operational terms, one has to overcome manifold challenges:

- First, cross-border areas have their particular position in both national and regional innovation systems with corresponding differences in legislation, educational systems etc. [36]. This particularly affects institutions, knowledge bases, networks and related multifaceted processes $[3,4,32,34,37-41]$.

- Second, innovation processes are dynamic, contextually contingent and reliant on learning in networks $[3,5,13,14,24,38,42-47]$. Innovation-driven interactions in a regional setting, for example, tend to be manifested through interorganisational relations embedded in local networks; this is also how innovation can acquire its systemic quality [44,48].

- Third, effectively connecting networks and relations across borders can be a challenge as such interactions do not naturally emerge in a cross-border region setting $[4,31,32]$. They need to be nurtured, not least due to socio-cultural factors such as differences in mentality, mindset, business practices and language barriers [32]. It has been argued that dedicated facilitators, dubbed as "innovation brokers", and increasingly also 
academic institutions [49-51], can fulfil important roles in catalysing relationships in cross-border settings [46,52]

Sohn believes that a border embodies a "third space in-between states" where "different representations, ideas, values and codes" are confronted [14]. At the same time, it has been demonstrated — both theoretically and empirically — that a border may also link different territories and represent opportunities [3,4,14,15,18,32]. In this respect, many researchers debate whether striving for a common cross-border space can be a viable strategy for fostering cross-border cooperation [20,53,54].

In this article, we perceive a cross-border region as one innovation space and here use of the second key concept becomes relevant- the concept of proximity $[7,8,10]$. This concept is important for better understanding of the aspects that can potentially foster and hinder the emergence of a cross-border innovation space. Previous research suggests that particularly cognitive and institutional, and often social or socio-cultural proximity along with shared learning systems are essential for regional innovation and fruitful crossborder cooperation $[3,5,7,8,13,55-58]$. Our research focusses on cognitive and institutional proximity, with the latter also including socio-cultural aspects.

Several authors make a case for a fine balance between a close affinity for actors to successfully cooperate-for example in knowledge infrastructures, organisational and technological cultures-and sufficient differences for cross-fertilisation effects to take place $[7,8,56,59-61]$. Knowledge infrastructure as one aspect of cognitive proximity was found to play a pivotal role for innovation and economic growth in regional and crossborder settings $[3,13,61]$. According to Smith (1997), knowledge infrastructure can be defined as "a complex of public and private organisations and institutions whose role is the production, maintenance, distribution, management and protection of knowledge." [62] Innovation brokers and academic institutions are part of it [63]. Knowledge infrastructure can in particular be manifested through research and development expenditures, specialisation patterns in knowledge and business areas, innovation capacity and various forms of partnerships between research organisations, educational bodies, transfer agencies and, importantly, their cooperation with businesses $[4,13]$. However, all of these tend to focus on regional and national needs, which limits the potential for knowledge transfer across borders [13]. This brings us to another important dimension of proximity-institutional.

Hoekman et al. (2009) demonstrated in their study comprising 29 European countries that institutional proximity is crucial for interregional research collaboration [56]. Almost a decade earlier, Koschatzky (2000) proved in his study that both institutional and cultural proximity matter for cross-border cooperation [64]. Economic and political contexts as well as government priorities and policies associated with institutional proximity are repeatedly mentioned in the literature as decisive for innovation and cross-border cooperation, they can enable or hinder related processes $[3,4,13,65]$. As to what institutional proximity denotes, many authors refer to formal and informal institutions. The former, for example, includes laws and regulations related to educational systems, intellectual property rights, etc., while the latter represents shared social values and norms, cultural habits and a common language $[3,4,7,8,41,66]$. Boschma (2005) argues that social (and organisational) proximity is embedded in institutional proximity [7]. Social proximity is related to trustbuilding, long-term relationships, (tacit) knowledge exchange and interactive learning-all of these are relevant for innovation to occur $[3,7,8,55,67]$.

Drawing on the above-mentioned literature on the different dimensions of proximity and RIS, we focus on cognitive and institutional proximity. We thereby also build on the work of Lundquist and Trippl who were the first to identify theoretical preconditions for the emergence of a cross-border innovation space $[3,4,13]$. These two dimensions of proximity comprise four key aspects in our conceptual framework: knowledge infrastructure, institutional set-up, economic and policy aspects and socio-cultural aspects. For the empirical analysis, we operationalised the four aspects with 13 assessment criteria (Table 1).

The question how to best benefit from existing proximity in a cross-border area leads us to the third main concept-hybridisation $[3,4,14,16-18]$. The two basic ideas of 
hybridisation are: first, a favourable balance of similarities and differences in knowledge infrastructures, institutional structures and processes, as well as socio-cultural, economic and policy contexts provide a sound basis for successful cross-border cooperation; second, more strategic use of relative regional strengths represents untapped potential for economic and social progress on both sides of the border.

Table 1. Conceptualisation of cognitive and institutional proximity, and their operationalisation.

\begin{tabular}{|c|c|c|}
\hline Proximity Dimension & Aspect & Assessment Criteria \\
\hline Cognitive & Knowledge infrastructure & $\begin{array}{l}\text { Role of academic institutions, innovation brokers and other bridging or } \\
\text { intermediary organisations } \\
\text { Engagement of academic institutions and innovation brokers in regional } \\
\text { and cross-border innovation-oriented cooperation } \\
\text { Cooperation between academia and businesses }\end{array}$ \\
\hline \multirow{3}{*}{ Institutional } & Institutional set-up & $\begin{array}{c}\text { Relevant legal and regulatory frameworks (e.g., on funding, labour } \\
\text { markets, intellectual property right regimes) } \\
\text { Mechanisms in place to facilitate innovation } \\
\text { Innovation network characteristics (e.g., who, what: regional, } \\
\text { cross-border, thematic) }\end{array}$ \\
\hline & $\begin{array}{l}\text { Economic and policy } \\
\text { aspects }\end{array}$ & $\begin{array}{c}\text { SMEs and their needs } \\
\text { Political agenda and priorities } \\
\text { Government support for innovation }\end{array}$ \\
\hline & Socio-cultural aspects & $\begin{array}{c}\text { Social values, norms, cultural habits and language } \\
\text { Hierarchical structures } \\
\text { Patterns of knowledge exchange (e.g., co-learning) } \\
\text { Trust }\end{array}$ \\
\hline
\end{tabular}

Source: own compilation based on $[3-5,8,13,15,41,55,56,64,65,68]$.

\section{Methodology and Empirical Basis}

The analysis presented in this article is based on the data collected as part of the Interreg project Food Pro-tec-ts. The project aimed at increasing sustainable, regional and high-quality food production in the cross-border region through fostering technological innovations in agri-food SMEs. Focus areas for innovation included water use in food production, animal welfare and health and transforming biomass into valuable products (e.g., animal feed). During the project, SMEs collaborated with innovation brokers and academic institutions in different technology clusters to develop innovations together (www.giqs.org/en/projects/foodprotects/, accessed on 12 March 2021). Food Pro-tec-ts was running between July 2016 and June 2020 in the Dutch-German cross-border region Euregio Rhein-Waal.

\subsection{Study Area}

Euregio Rhein-Waal is one of the six Dutch-German cross-border regions established among the first in Europe in 1973. The region is categorised as an integrated microcross-border region due to its size $\left(\mathrm{km}^{2}\right)$, population density and high intensity of cooperation [69]. Euregio Rhein-Waal extends over an area of $8663 \mathrm{~km}^{2}$ with a population of around 4.2 million. Local authorities are the ones typically driving cross-border cooperation in such regions [69].

The Euregio Rhein-Waal comprises the districts (Kreise) of Kleve and Wesel and the cities of Duisburg and Düsseldorf on the German side, and a large part of the province of Gelderland with the parts of Arnhem-Nijmegen, West-Veluwe, Zuid-West-Gelderland, parts of northeast Brabant and the northern part of the province of Limburg on the Dutch side (see Figure 1). Not all municipalities within these districts and provinces are members of this cross-border region-it encompasses 20 German and 29 Dutch municipalities. Table 2 below details basic data for the Dutch and German regions in the Euregio Rhein-Waal. 


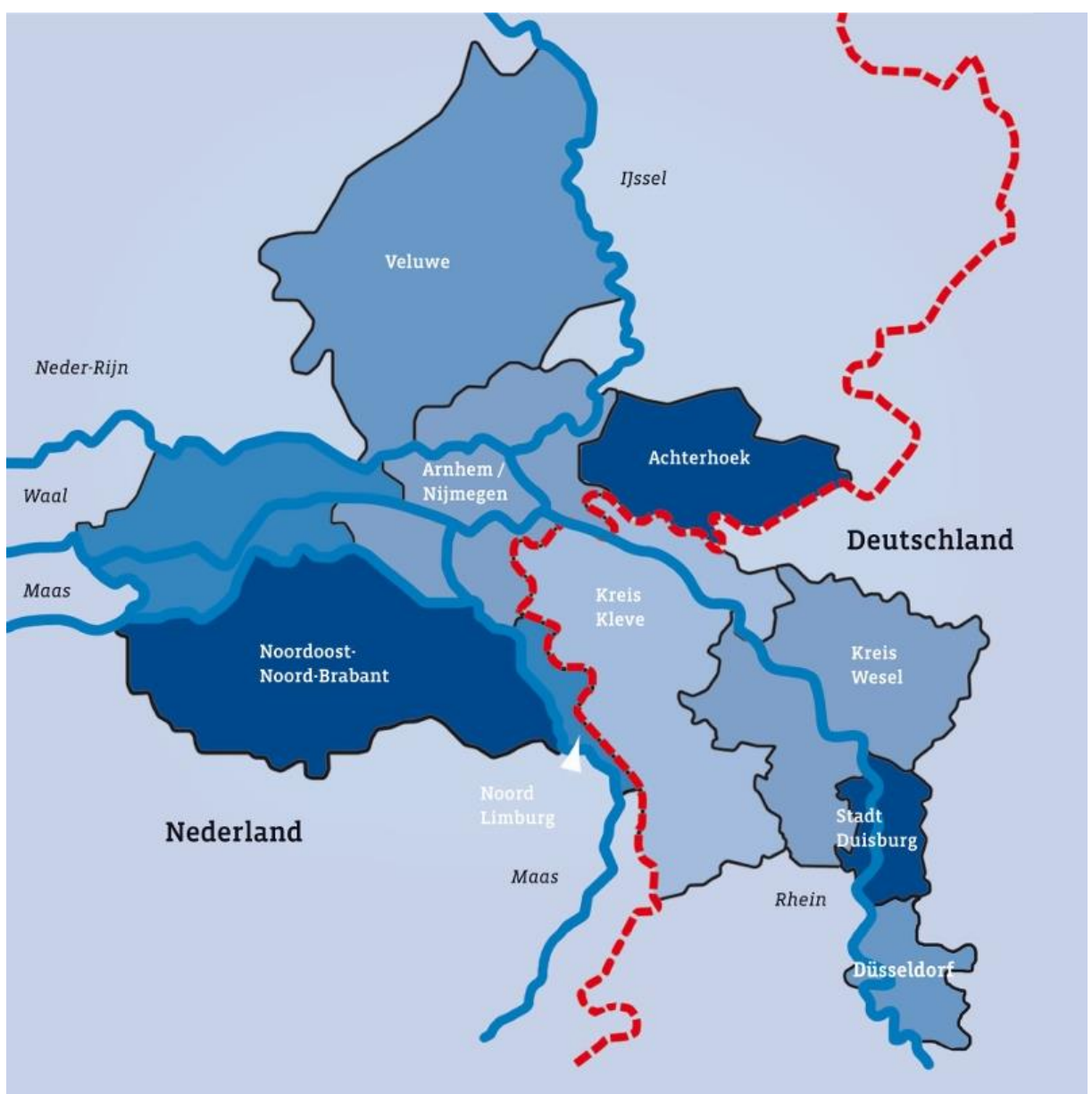

Figure 1. The map of the Euregio Rhein-Waal. Source: https:/ /www.euregio.org/werkgebied/, (accessed on 19 April 2021).

Table 2. Basic data for the Dutch and German regions in the Euregio Rhein-Waal.

\begin{tabular}{|c|c|c|}
\hline $\begin{array}{l}\text { Indicator } \\
\text { (NUTS 2) } \\
\text { (NUTS 3, COROP) }\end{array}$ & $\begin{array}{l}\text { Dutch Region } \\
\text { (NL22 Gelderland) } \\
\text { (15 Arnhem/Nijm. } \\
35 \text { Noordoost-N.-Brabant) }\end{array}$ & $\begin{array}{l}\text { German Region } \\
\text { (DEA1 Düsseldorf) } \\
\text { (DEA1B Kleve, } \\
\text { DEA1F Wesel) }\end{array}$ \\
\hline Population density (NUTS 3; 2018) & $482-811$ & $258-458$ \\
\hline $\begin{array}{l}\text { GDP at current market prices (NUTS 3; 2018; Euro per inhabitant; } \\
\text { as \% of EU average) }\end{array}$ & $122-140$ & $93-99$ \\
\hline $\begin{array}{l}\text { Importance of agri-food sector (share of food-related employment } \\
\text { in total manufacturing; \%; 2018) }\end{array}$ & 21.8 & 8.0 \\
\hline $\begin{array}{l}\text { Human resources in science and technology (2017) } \\
\text { Scientists \& engineers in \% of economically active persons }\end{array}$ & 9.9 & 7.4 \\
\hline $\begin{array}{l}\text { R\&D intensity (2018) } \\
\text { Expenditure per inhabitant }(€ ; \text { NL = Oost-Nederland, 2018) } \\
\text { Expenditure in \% of GDP (\%; NL = Oost-Nederland, 2018) }\end{array}$ & $\begin{array}{l}775 \\
2.07\end{array}$ & $\begin{array}{l}794 \\
1.96\end{array}$ \\
\hline $\begin{array}{ll} & \text { No. of academic institutions } \\
- & \text { Traditional Universities } \\
\text { - } & \text { Universities of Applied Sciences }\end{array}$ & $\begin{array}{c}3 \\
11\end{array}$ & $\begin{array}{l}3 \\
5\end{array}$ \\
\hline
\end{tabular}

Data sources: [70-73] (accessed on 6 December 2020).

\subsection{Study Approach and Methods}

A qualitative research design was chosen to obtain a comprehensive understanding of the issue, explore the role of contextual factors, and reveal underlying linkages. Qualitative 
methods also allow to examine the perspectives of respondents and unravel rationale for their actions [74,75].

Based on the aims of our study, academic institutions, such as traditional universities and Universities of Applied Sciences, innovation broker organisations and agri-food SMEs were identified as target interviewees. Key selection criteria included the location of organisations as well as experience in agri-food innovation and in Interreg projects. We pursued a mixed sampling strategy to identify our respondents: ten respondents were found through the desk research conducted in the Food Pro-Tec-ts project, while nine were identified through snowball sampling. Only three respondents out of all were directly engaged in the Food Pro-Tec-ts project.

The data were collected at two levels: "helicopter view" and case-specific interviews, which corresponds with a broader and narrower level in qualitative studies [76]. As innovation brokers tend to have ample experience in interorganisational, and often in interregional and cross-border innovation cooperation, we included them in the sample to capture their broad perspective and tacit knowledge on agri-food innovation in their region. Academic institutions interested us in view of their engagement with innovation in SMEs. In total, nine helicopter view interviews were conducted where the respondents provided a multitude of contextual data. Ten case-specific interviews were carried out to support a more in-depth analysis. They included interviews with SMEs on concrete innovation experiences and interviews with innovation brokers related to specific innovation projects. It should be noted that for the purposes of our study we understood innovation in a more encompassing sense, that is including its technological, social and management or organisational dimensions. However, the interviews demonstrated that our respondents tended to see innovation as predominantly technological, such as the introduction of new products and services or their improvement. Overall, the sample comprised nineteen selected actors: thirteen respondents from innovation broker organisations, four respondents from academic institutions (some of these were also classified and counted as "innovation brokers" due to corresponding functions) and six agri-food SMEs (all those respondents were SME owners or co-owners). We aimed at a balanced representation of Dutch (eight) and German (nine) respondents. The general characteristics of all respondents are detailed in Table A1 in Appendix A.

All interview questions (available upon request) were elaborated based on the conceptual framework presented earlier. The interviews were semi-structured and carried out between April and June 2020. Due to the disruptive effect of the COVID-19 pandemic, the data were collected via online interviews using various communication tools such as Skype, Microsoft Teams, Webex and Zoom. In total, twelve interviews were carried out in English and seven in German. The interviews lasted between 1 and $2 \mathrm{~h}$. All interviews were recorded and fully transcribed.

We had started to continuously reflect on the data from each interview before the actual data analysis began. This approach is in line with grounded theory techniques indicating that analysis should be continuous and inseparable from data collection [77-80]. Several data coding techniques such as Attribute coding and Deductive coding (so-called "First Cycle coding") as well as a Focused Coding method ("Second Cycle coding") ensured rigour in the analytical process $[77,81]$.

Based on the analysis of our interview data, similarities and differences between the Dutch and German regions were scrutinised. Context-specificity was examined to better understand how particular findings and local conditions are related. Selected quotes from the interview transcripts are used in Section 4 to illustrate important issues and patterns.

\section{Comparative Analysis of Dutch and German Regions in the Cross-Border Region Euregio Rhein-Waal}

In this section, we present the results of our analysis based on the three research questions: 
- Similarities and differences between the two regions in how academic institutions and innovation brokers support innovation in agri-food SMEs (Section 4.1).

- Relative strengths and the regional context factors that limit and enable these strengths in innovation-driven cooperation (Section 4.2).

- $\quad$ Traits of a cross-border innovation space and of hybridisation potentials (Section 4.3).

In the presentation of results, we will refer to the assessment criteria of the concept of cognitive and institutional proximity introduced earlier (Table 1). The interpretation of the data will follow in Section 5.

\subsection{Similarities and Differences between the Two Regions in How Academic Institutions and Innovation Brokers Support Innovation in Agri-Food SMEs}

The most prominent similarities between the two regions relate to the role of academic institutions and innovation brokers, cooperation between academia and businesses, innovation network characteristics, trust, engagement of academic institutions and innovation brokers in regional and cross-border innovation-oriented cooperation, social values, norms, cultural habits and language, and SMEs' needs.

The starting point of our research was the assumption that academic institutions, more specifically traditional universities or Universities of Applied Sciences, research institutes and innovation brokers play a central role in supporting agri-food SMEs in developing innovation. We found that while academic institutions and innovation brokers are essential for the SMEs in both regions, research institutes seem to play only a limited role, i.e., mostly in task-specific, short-term cooperation. At the same time, the relationships between SMEs and academic institutions observed in the two regions go beyond ad hoc interactions such as consultation. Academic institutions were found to be rather present in both regions (see Table 2), and SMEs tended to see them and innovation brokers as long-term strategic partners in innovation cooperation.

Academic institutions in both regions were found to play a dual role in supporting agrifood SMEs: each respondent employed at a Dutch or German university acknowledged their side role as an innovation broker. Innovation brokers and academic institutions were revealed to perform diverse functions, for example as networkers, matchmakers, advisers (e.g., on funding, (cross-border) market, legal, financial, cultural and language issues), facilitators as well as versatile experts providing ad-hoc support in innovation and cooperation matters. Our data showed that this diversified support is very much appreciated by agri-food SMEs in both regions.

Most respondents from academic institutions and innovation broker organisations are convinced that moving from solely formal cooperation at the beginning to more informal trust-based cooperation is crucial for effective regional and cross-border cooperation. In our data we observed that particularly alumni networks and personal relationships developed through long-standing cooperation and in common interest areas (e.g., plant-based protein, digitalisation in agriculture) play a positive role. Such networks and relationships foster direct, regular and informal cooperation in both regions. One of the SME owners from the Dutch region acknowledged that "cooperation with [University 1] and [University 2] is basically built on [his] personal relationships because [he] did a PhD and [had] a postdoc [position] in these academic institutions."

An underdeveloped regional and cross-border network was voiced by the SME owners as one of the biggest hurdles in innovation activities. Innovation brokers and academic institutions in both regions suggested network development through memberships in relevant thematic or "place-based" networks as well as cooperation in regional, crossborder and EU projects. The quote from one of the SME owners illustrates the significance of a well-developed network for SMEs: "When you focus on good long-term relationships, you can even use the network of your network partner [for innovation activities and marketing], not only your own. By this you can extend your network dramatically, like you would never have been able to do otherwise." Related to that, the quote from an innovation broker shows how an innovation broker can help SMEs in, for instance, starting business 
activity across the border: "Innovation brokers often know the business environment across the border where an SME might want to expand their business, such as conditions, specificities, limitations, benefits, right people to get in touch with, common mistakes of businesses and ways to avoid them, business practices (attitudes, ways of communication, what to pay attention to etc.). That's how we help SMEs to go across the border."

Agri-food SMEs in both regions also have similar needs when innovating:

- Access to funding, such as subsidies, various grants as part of regional and EU-funded projects, contacts of investors.

- $\quad$ Exchanging knowledge, sharing experiences and getting access to resources (e.g., lab facilities or equipment) through networking.

- New partnerships for product or market development and recruiting new employees.

- Access to markets and advice on cultural specificities of international markets.

The last point seemed to be particularly relevant for the Dutch agri-food SMEs where neighbouring and international markets are much more important.

As to the differences, six of them were derived from the interview data (Table 3). These could be to a varied extent attributed to the assessment criteria of the conceptual framework (see Table 1). Table 3 below provides an overview of the six key differences supported by selected quotes.

Overall, our data demonstrated that SMEs in the Dutch region tend to find close and continuous cooperation with academic institutions and innovation brokers beneficial, while SMEs in the German region seem to seek more targeted inputs in such cooperation.

Innovation brokers were also found to function differently in the two regions. In the Dutch region, they are often separate and independent organisations facilitating innovationoriented cooperation, while direct cooperation between SMEs and academic institutions is limited. This kind of innovation brokers tends to be less present in the German region, where direct contacts between SMEs and academic institutions are prevailing. In the German region, the role of innovation brokers in connecting academia with businessesthe so-called Third Mission of academic institutions-is often performed by knowledge or technology transfer offices.

With the lesser significance of innovation brokers in the German region compared to the Dutch region, regional and national professional associations-so-called Verbände and Vereine-seem to play a much more significant role. Our data shows that membership in such organisations allows German SMEs to have direct access to relevant resources and networks. Comparable networks exist in the Dutch region as well, but the SMEs there tend to consider them as only complementary.

\subsection{Relative Strengths and the Regional Context Factors That Limit and Enable Them}

The differences in innovation structures and processes identified above can be seen as the relative strengths of a region. We labelled them as "relative" because they work well for the region they are embedded in and because the assessment is based on the respondents' views. If used strategically, some strengths might be complementary and therefore potentially beneficial in cross-border cooperation.

In the following, we identify these relative strengths to understand:

- the complementarities between the two regions that can drive joint cross-border innovation,

- $\quad$ how one region can compensate its weaknesses cooperating with the other.

Table 4 provides an overview of eight relative strengths, and associates these with regional context factors that limit or enable them. The strengths are detailed in the first column, followed by a short explanation of how a particular regional context factor is limiting or enabling. 
Table 3. Six key differences in how academic institutions and innovation brokers support innovation in agri-food SMEs.

\section{Comparative Aspec}

\section{Related Criteria}

- Political agenda and priorities

Significance of agri-food innovation in the regional agenda and in innovation support

- Government support for innovation

- Mechanisms in place to facilitate innovation

Differences between the Regions

In the Dutch region, government and academia have a primary interest in supporting agri-food innovation.

Characteristic of this is the establishment of spaces dedicated to agri-food innovation with related intermediary organisations, advisory services, personnel training etc.

In the German economy agri-food SMEs play a much lesser role.

SMEs in the Dutch region see academic institutions as a main innovation partner therefore seeking cooperation (in fewer

- $\quad$ Role of academic institutions, innovation brokers and "bridging" or intermediary organisations

- Cooperation between academia and businesses

Key innovation partners for SMEs

- SMEs and their needs

- Innovation network characteristics

- Patterns of knowledge exchange

- $\quad$ Trust instances-with research institutes). In

cooperation with academic institutions, the SMEs particularly need know-how or facilities

(e.g., lab or advanced equipment).

In contrast, SMEs in the German region consider other SMEs and larger businesses key innovation partners. This is because SMEs tend to believe that traditional universities are rather theoretical and therefore disconnected from their business reality. Our data however indicated that this tendency is slowly

changing - in many ways also thanks to increasing innovation-oriented multi-actor research funding of the EU.

\section{Illustrative Quotes}

"Brightlands Campus Greenport Venlo [located in a neighbouring to Euregio Rhein-Waal cross-border region 'Euregio

Rhein-Maas-Nord'] is one of the six Greenports in the Netherlands with a high concentration of agribusiness and the only campus of such kind outside the western economic core of the country." (University actor from the Dutch region and cross-border innovation broker)

"We told this research institute about our idea-they were fascinated. We soon got the funding and combined our knowledge ... They have absolutely top people there and excellent connections. That helped tremendously to get the right people at the right moment for the right procedures, so in two years we got everything in place." (SME from the Dutch region)

Large companies naturally have a great deal of know-how and often play a major role in what goes on the market. ... These are just things that no small companies do.... That is often the 'why' for building a consortium-it is attractive for small companies to work with big ones." (University actor and innovation broker from the German region) 
Table 3. Cont

\section{Comparative Aspect}

Related Criteria

- Role of academic institutions, innovation brokers and "bridging" / intermediary organisations

Intermediaries as a link versus direct contact

- Cooperation between academia and businesses

- $\quad$ SMEs and their needs

- Innovation network characteristics

- Trust

\section{Differences between the Regions}

In the Dutch region, innovation brokers play a pivotal role as intermediaries between academic institutions and SMEs. SMEs often get in touch with innovation brokers when they need funding, particular knowledge, expanding their network and marketing

products, not least because of their network.

Direct cooperation between SMEs and

academic institutions rarely occurs.

In the German region cooperation between academic institutions and SMEs tends to be direct without resorting to intermediaries. In

rare instances organisations with an innovation broker function such as $I H K$

(Chamber of Commerce) or a business development agency might be involved in arranging the cooperation. Interestingly, German SMEs tend to strategically use their membership in professional associations and place-based networks to acquire innovation support.

Strategic and continuous cooperation between academia, industry, and government (e.g., Triple Helix) is more common in the Dutch

- Role of academic institutions, innovation brokers and "bridging" / intermediary organisations

Nature of cooperation between academic institutions and SMEs and its impact on co-learning and knowledge exchange
- Cooperation between academia and businesses

- Mechanisms in place to facilitate innovation

- Hierarchical structures

- Patterns of knowledge exchange
(

kind of cooperation is a new way of working where innovation projects are jointly designed and implemented. Dedicated physical spaces are sometimes provided for such cooperation. In the German region, the Third Mission is part of academic institutions' functions. The main difference is that Third Mission implies more ad-hoc than continuous cooperation and

features clear-cut boundaries between institutions.
"In the Netherlands, SMEs generally access external knowledge and relevant partners through a mediator. What does a mediator mean? [Here in the German region], we are also employed as agents who look for companies and also mainly on the Dutch side. Here on the German side less so." (University actor and innovation broker in the German region)

"We have eleven institutes at the university, which naturally maintain their contacts with the industries that are important to them.

Departments also have many contacts through their alumni network." (University actor and innovation broker in the German region)

"You see many physical places in the Netherlands, where businesses, educational institutions, public authorities-three pillars

of Triple Helix - share the space. One is

'Brightlands Campus' in Venlo, which focusses on healthy food and healthy living.

... I guess, such places are something typically Dutch. " (University actor from the Dutch region, innovation broker)

"[As a knowledge transfer office] we connect business with university and vice versa starting from student projects and bringing students into jobs to connecting ideas in SMEs with the expertise in a university." (University actor and innovation broker from the German region) 
Table 3. Cont.

\section{Comparative Aspect}

Multifunctional institutions providing innovation support to businesses versus specialised organisations providing innovation support

\section{Related Criteria}

- $\quad$ Relevant legal and regulatory frameworks

- Mechanisms in place to facilitate innovation

\section{Differences between the Regions}

In the Dutch region, financial institutions (e.g. banks, regional development agencies funded by government to carry out investmen activities) perform multiple functions such as financial, regional development, brokering innovation activities. Such an institution can therefore support SMEs in various ways: funding their activities, networking and matchmaking, consulting etc.

Due to different institutional structures, such organisations function as separate in the German region. Public banks can fund individual business activities, but they have limited business development functions. Other organisations (e.g., Chambers of Commerce) are responsible for fostering regional development, which also includes SME support schemes. Generally different kinds of support are provided by different institutions in the German region.

Regional actors in the Dutch region were often referred to as more open-minded, having a flexible mindset, willing to experiment and

Mindset of key actors in relation to business practices and innovation
- $\quad$ Social values, norms, cultural habits and language

- Patterns of knowledge exchange flexible in cooperation.

At the same time, the actors in the German region were predominantly described as more formal, structured in their work approaches and quality- and data-driven.

\section{Illustrative Quotes}

"Development agencies are part of Dutch public banks. These agencies often take part in our projects. On the German side everything is organised a bit differently. In the last two years I got in touch with a public investment bank in North Rhein-Westphalia. However, this bank does only financing and has limited development tasks. It is a pity that these are so separated because there should be a straightforward linkage from development into public finance and into venture capital. Organisations like the Wirtschaftsförderung in Germany provide support for SMEs in innovation." (Cross-border innovation broker) "We try to work together with other cluster organisations. That is why we want to cooperate with IHK and Wirtschaftsförderung in Germany, but it is rather difficult because they have a different focus compared to what we have in the Netherlands." (Innovation broker, Dutch region)

"German partners tend to have a different approach and they, for example, make us commit to establishing firm regulations and sticking to them. The project gains from it. Working together with partners like that

keeps you focussed on the agreed indicators, methods and processes. We have different

qualities but together they make a great combination." (SME from the Dutch region) 
Table 4. Regional context factors that limit and enable the identified strengths.

\section{Strength}

Significance of agri-food innovation and associated concentration of academic and practitioner expertise

Strong innovation partners and associated strategic academia-industry-government cooperation

Manifold intermediary organisations facilitating innovation processes

Capacity of professional associations and place-based networks to support innovation

Direct interaction between academic institutions and SMEs

Open-mindedness, and flexible mindsets supporting adaptive management

More formal and structured mindset fostering goal orientation and providing planning security

\section{How the Regional Context Factors Limit or Enable This Strength}

The agri-food sector, innovation and agri-food start-ups play a particularly important role in the Dutch region (as well as at the national level). A vast amount of academic and practitioner know-how around agri-food topics has been accumulated during the continuous search for best practices and technological advances. Various innovation support is available, including funding of regional innovation clusters, hubs or accelerators on water use, biomass, food etc., as well as (partial) funding of innovation brokers and their organisations. In the German region, other industries like automobile, engineering, ICT are prioritised by regional and national governments; agri-food is much less important.

Triple Helix cooperation was found to be typical in the Dutch region (as well as nationally). Regional and national governments tend to strategically plan, fund and promote it. An example is funding of physical spaces dedicated to enhancing this type of cooperation (e.g., campuses or so-called valleys, like Brightlands Campus Greenport Venlo (www.greenportvenlo.eu/campus, accessed on 9 November 2020). In the German region, cooperation tends to be project-based and ad hoc. German traditional universities in particular are still seen as rather theoretical and less oriented towards business realities. Unlike them, Dutch traditional universities are perceived as very entrepreneurial and often connected with innovation clusters, hubs or accelerators.

In the Dutch region, intermediary organisations are often funded by regional or national governments to stimulate innovation processes. Our data showed that several innovation brokers are in some ways (e.g., legal, administrative, financial) connected to local, regional—or in one case even European—government that vested them with additional functions. Such organisations are perceived by all actors as versatile and important for effective cooperation. In the German region (and in Germany), government tends to engage in agri-food innovation to a much lesser extent. The somewhat comparable IHK has a much wider portfolio.

Professional associations are traditionally rather influential in German industry and government circles, and membership in such associations and networks is common. Through them German SMEs can obtain direct access to resources that would have been difficult to access otherwise.

Universities of Applied Sciences have always been more practice-oriented in Germany. They cooperate directly with SMEs through their Third Mission offices, often on a task basis (e.g., accessing specific know-how, facilities or advanced equipment). This has the advantage of a more targeted and potentially more efficient, problem-driven interaction.

In the Dutch region, organisations involved in agri-food innovation tend to have multiple functions, for example networking, consulting, financing etc. This fosters a more coordinated and effective support for SMEs and can enhance synergies. The versatility of such organisations allows to reduce the silo effect and risk of disconnection that can be a problem with more dedicated single function organisations that are characteristic of Germany. A notable exception are German IHKs.

Common features of the Dutch mindset and culture are willingness to learn, non-linear thinking and associated flexibility. These very characteristics are deemed key ingredients of successful innovation projects and processes.

More precise (data-oriented), formal and quality-driven mindset are typical of German approaches. In line with that, innovation actors from the German region were characterised in terms of their well-structured and consequent way of working. 


\subsection{Traits of a Cross-Border Innovation Space and of Hybridisation Potentials}

The strengths in the table above are indicative of the significant potential that can be harnessed in the management of cross-border innovation projects. The question is whether the idea of complementarities can be expressed in terms of a cross-border innovation space. As formulated in our third research question, we ask what traits of a cross-border innovation space and hybridisation are already present in the cross-border region? We use the assessment criteria from our conceptual framework to provide a more differentiated assessment:

- Knowledge infrastructure is separated with only a few academic institutions, innovation brokers and similar intermediary organisations working across the border. Moreover, the way academia and businesses cooperate differs a lot between the two regions and complementarities are not yet used. Both are indicative of an underutilised potential for hybridisation that could fairly easily be remedied. Currently the main driver and opportunity for engagement in cross-border innovation cooperation is the Interreg programme. In this respect, the Dutch SMEs we interviewed unanimously believe that this programme is the best innovation support currently available for SMEs and start-ups as well as the best means for cross-border cooperation.

- The differences in institutional set-ups might well be the biggest hurdle. Relevant legal and regulatory frameworks related to employment, funding, educational programmes, etc. hinder cross-border cooperation. The same applies to the mechanisms in place for facilitating innovation and innovation network characteristics. All of these would be hard to overcome. Related to innovation networks as part of institutional set-ups, many SME owners and innovation brokers expressed that a much-needed cross-border network is essentially absent and that the awareness of how business is done across the border is limited. These imply potentials for hybridisation that could relatively easily be exploited.

- In respect of economic aspects and policy frameworks, SMEs' needs were found to be almost identical, while political agendas and priorities are profoundly different. Related to this also the level of government support provided for agri-food innovation varies significantly. All these aspects are largely determined at the national level and are therefore hard to overcome.

- Many respondents emphasised the importance of social values, norms, cultural habits and language in cross-border cooperation. Innovation actors in the Dutch region were often described as more commercially oriented, flexible in work processes and creative, while their German counterparts were referred to as focussed on agreed plans, methods and processes and more reliant on data. More importantly, about half of the interviewees saw the cooperation as an opportunity to learn from each other, improve practices and consequently achieve a bigger impact in cross-border projects. Interestingly, these relative strengths represent the only potential for hybridisation that is already recognised and appreciated by the respondents.

The SME owners and innovation brokers we interviewed seemed to be aware of a certain potential of cross-border cooperation. However, is there an opportunity for thinking of and building a cross-border innovation space? Some of our respondents had rather precise ideas of what could be done in this respect, for instance: the establishment of a centralised database with "cross-border innovation actors" working in the vicinity of the border was a central proposition. Other suggestions included the organisation of regular thematic events aiming to bring SMEs together with bigger companies and potential customers, and innovation brokers taking on an "ambassador" function to advise on opportunities and conditions as well as identifying businesses to partner with across the border. 


\section{Discussion}

In this section we will reflect on our findings using the three concepts introduced at the beginning: innovation space, proximity and hybridisation. The discussion is again structured by the three research questions:

(1) What are the similarities and differences between the two regions in how academic institutions and innovation brokers support innovation in agri-food SMEs?

(2) What are the relative strengths of each of the two regions in innovation-driven cooperation?

(3) What traits of a cross-border innovation space and hybridisation are already present in the cross-border region and how can hybridisation effects be fostered?

5.1. Similarities and Differences between the Two Regions in the Role of Academic Institutions and Innovation Brokers in Supporting Innovation in Agri-Food SMEs

Our study demonstrates that academic institutions and innovation brokers in both regions play critical roles in supporting agri-food SMEs in innovation. Based on our interview data and in line with the literature, we can summarise these functions as follows:

- Networking, matchmaking and brokering (articulation of SMEs' needs, connecting with suitable partners for knowledge exchange purposes, negotiation and closing a deal etc. as well as facilitating innovation-driven cooperation) [24,27,33,46,82,83],

- Providing access to funding (informing about available subsidies, help with funding applications, engaging SMEs in relevant projects funding their innovation activities etc.) $[24,28,82,84]$,

- Support in regional and cross-border marketing (promoting project results and branding an SME, identifying best marketing strategies, informing about the specificities of the market across the border, common mistakes of other businesses failed before and ways to avoid them) $[27,46]$,

- Sharing resources (e.g., lab facilities or equipment) [32],

- Contributing to the recruitment of new employees (e.g., through student exchange and other partnership schemes) [33]

- Advising on various issues, like legal (e.g., contracts, intellectual property rights) and socio-cultural (e.g., drawing attention to differing business practices across the border) $[27,46,82]$.

The work of Fisher (2011) [83] and Kauffeld-Monz and Fritsch (2013) [25] supports our findings related to the complementary innovation broker functions that academic institutions have. However, in this discussion, we need to distinguish between traditional universities, Universities of Applied Sciences and research institutes [49,51,85]. Most Universities of Applied Sciences tend to have long-standing connections with SMEs (e.g., in our study with agri-food SMEs) $[49,86,87]$ and are in some cases seen as the main innovation partner (Dutch region). The same applies much less to traditional universities. It should however be noted that in the last 10-15 years, academic institutions have generally put more emphasis on the relevance and applicability of scientific and technological knowledge, thereby also becoming closer to businesses $[49,51]$. Some authors argue that this trend has actually led to the emergence of Triple Helix and Third Mission concepts $[49,50]$.

There is one main difference between the two regions, which plays an important role in this discussion. We observed different kinds of academia-business relations in the two regions: a distance between the two "realms" where SMEs directly get in touch with academic institutions for short-term and targeted inputs required for innovation (this corresponds with the well-developed Third Mission in Germany), and more strategic Triple Helix cooperation prevalent in the Dutch region, which often goes beyond project relations and is facilitated by innovation brokers. We conclude that innovation brokers could still play a much more significant role in the German region in connecting various institutions and actors with similar interests and complementary competences and fostering their cooperation, stimulating knowledge exchange, and spanning boundaries $[24,50,88]$. 


\subsection{Relative Strengths of Each of the Two Regions in Innovation-Driven Cooperation}

A sufficient proximity, particularly in knowledge bases and technical and organisational know-how, is an important precondition for effective cross-border cooperation $[59,60]$. However, it is the differences that provide room for tapping into complementarities and creating synergies. This is also in line with the work of other scholars $[3,4,7,8,13]$ and van den Broek (2018) [32] who emphasises that cross-border cooperation is in fact "driven by differences in culture, labour market or business opportunities".

Taking this further, we see some of the differences between the two regions as relative strengths that each region can contribute in cross-border cooperation. To illustrate the importance of relative strengths and their more strategic use, we take a closer look at knowledge sharing and learning, and the role of professional associations and academiaindustry cooperation.

Due to the enormous agri-food knowledge base present in academia and practice in the Dutch region (and in the Netherlands as a whole) and the long-standing focus on technological advances supported by regional and national governments, the agri-food sector and related innovation system is extraordinary. This is not the case in the German region, where the agri-food sector plays a significantly less prominent role. Cooperation and knowledge exchange with the Dutch partners on agri-food topics could therefore be very beneficial.

At the same time, professional associations have a rather long history of being influential in industry and government circles in the German region. Membership in such associations and networks is common and provides SMEs with direct access to resources, knowledge and partners which would have been arduous to access otherwise due to a lesser presence of innovation brokers. What regional innovation actors in the Dutch region could learn from the German partners is the potentially important mediating role of professional associations at the interfaces of business (and economic) development, academic institutions and policy.

\subsection{From Regional Strengths to Hybridisation in a Cross-Border Innovation Space}

The two examples of the regional strengths above-encompassing agri-food knowledge base and strong professional associations-illustrate how regional innovation actors can mutually benefit from cross-border cooperation. When examining in Section 4.3 what traits of hybridisation are already present in this cross-border innovation space, we reckoned that there are some, while other major opportunities remain untapped yet. The latter relate to knowledge infrastructure, cross-border innovation networks and differences in mindsets and approaches.

Currently, knowledge infrastructures are largely separated with only a few academic institutions and innovation brokers systematically engaged in cross-border cooperation related to agri-food innovation. Professional associations with their business networks could support cross-border interactions, however nowadays they tend to stop at the border, and functioning cross-border networks are only in their infancy.

SMEs particularly long for cross-border networks to be able to obtain more information about similar businesses across the border. This is where academic institutions and innovation brokers as part of this knowledge infrastructure are in a position to foster more intensive academia-business exchanges and forge new partnerships by their engagement in cross-border innovation projects, and sometimes through personal connections. They can, for example, set up joint initiatives on applied innovation research, organise matchmaking events and workshops to exchange experiences on the topics relevant for agri-food SMEs, merge knowledge repositories, contribute to establishing a centralised cross-border database of research and business contacts. Innovation brokers specifically can take on ambassador functions to increase the awareness of how business is done across the border, including the differences in culture and business practices.

These findings are largely in line with the work of many scholars. Van den Broek et al. (2019), for one, underscored that universities can contribute to the development of a 
cross-border innovation space using their resources and reputation [33]. Substantial prior research of other authors supports our closely related finding that dedicated innovation brokers and academic institutions can play a key role in facilitating multi-actor innovation partnerships $[24,25,27,46,82,83]$, especially in a cross-border setting through "bridging institutional and cultural gaps and supporting learning between partners" [52].

With insufficiently connected knowledge infrastructures of the two neighbouring regions and largely underdeveloped cross-border networks to date, the Interreg programme was unanimously recognised as in many respects the only catalyst of cross-border cooperation and a key connection point between SMEs, academic institutions and innovation brokers (this is in line with van den Broek et al. [33]). This is due to the versatile support of the Euregio Rhein-Waal office, including its innovation broker functions such as matchmaking and facilitating multi-actor partnerships, assisting in projects and consulting about various issues. Those functions of Interreg offices as a cross-border information centre, network facilitator and supporting institution are also confirmed by the findings of Klatt and Herrmann [36] and Trippl [13]. The latter emphasises the importance of knowing the precise differences in institutional contexts, and of fostering knowledge exchange across borders.

Overall, multiple opportunities for better utilisation of complementary strengths were not sufficiently recognised by the respondents just yet. The exception is social values, norms, cultural habits and language where the interviewees tended to acknowledge relative strengths of the counterparts from across the border. This confirms the conclusion of van den Broek that "mostly it is not an active act of ignorance or unwillingness to work across the border, rather it seems to be a lack of awareness of possibilities" [32].

\section{Conclusions}

"The big benefit of the cross-border region is that one can take advantage of various abilities and ways of looking at things of both regions. One is more thorough, and the other is more like taking the leap and taking the risk. I think this combination is fantastic." [Dutch SME].

In the context of the Interreg programme, all cross-border regions where regional actors from two (or more) regions cooperate on innovation issues can be considered as innovation spaces. In this analysis, we showed that regional actors can go far beyond by applying a more strategic approach towards raising innovation capacity. It requires factoring in contextual specificities, managing tensions and promoting interactions across the border. This is where academic institutions and innovation brokers can play out their strengths.

Related to our three research questions, we conclude:

- There are a number of similarities and differences between the two regions in how academic institutions and innovation brokers support innovation in agri-food SMEs. The similarities we identified provide a common ground for regional innovation actors. However, it is the differences and relative regional strengths that allow crossfertilisation. The take-home message for regional innovation actors and Interreg is that acknowledging mutual differences between border regions in economic, institutional and social structures, knowledge and technological capacity, political visions and cultural identities, and more importantly-valorising them, is necessary to enable cross-fertilisation and enhance cross-border cooperation.

- Eight relative strengths of the two regions in innovation-driven cooperation have been identified along with regional context factors that limit or enable them. If used strategically, these strengths can considerably benefit cross-border cooperation.

- Up to now only limited traits of a cross-border innovation space and of hybridisation are present in the cross-border region. Generally, multiple opportunities for a better utilisation of complementary strengths are hardly recognised by regional innovation actors, let alone their strategic use in cross-border cooperation. 
Related to the contribution to the scientific debate, our study has showed that proximity is crucial for a better understanding of the functioning of a cross-border innovation space. We focussed on cognitive and institutional proximity which had already been recognised in earlier research as essential for fruitful regional innovation and cross-border cooperation. On this basis, we have for the first time empirically applied the concept of hybridisation to a cross-border innovation space, thereby also offering consolidated evidence on the important functions of academic institutions and innovation brokers. We have demonstrated that the concept of hybridisation, which has virtually not been applied yet to cross-border innovation contexts, can help to raise awareness of complementary regional strengths and their strategic use. A great example is the immense agri-food knowledge accumulated in academia and practice in the Dutch region and the expertise in other sectors in the German region. Bringing both together could lead to substantial cross-fertilisation. Another example is learning from the mediating role that professional associations fulfil in the German region at the interfaces of business and economic development, academic institutions and policy.

Even though our analysis focussed on the agri-food sector and one cross-border region, we contend that our findings are more widely relevant for the understanding of regional innovation processes. They might nevertheless apply slightly less in cross-border regions with larger differences in economic and innovation systems. We are convinced that our exploratory analysis opens manifold opportunities for larger-scale empirical studies aimed at statistical assessment of the relationships presented here and generalisation of findings.

Concluding on the implications for policy and practice, we believe our findings can be particularly useful for those involved in cross-border cooperation projects and related governing institutions such as Interreg offices, regional and national governments, as well as knowledge providers like academic and research institutions. The cross-border innovation space and hybridisation concepts presented in this article are an opportunity for a renewal of cross-border cooperation strategies in policy and practice. We believe that a wider application of the two concepts can lead to a more contemporary "branding" of Interreg projects. This in turn seems important in view of the future of the Interreg Europe programme as well as the implementation of the EU's Territorial Agenda 2030.

Author Contributions: Conceptualisation: M.K. and S.N. supported by L.K., K.K. and G.B.; Methodology: M.K. and S.N., supported by L.K., K.K., G.B. and H.S.; Data analysis: M.K. supported by K.K.; Overall lead, original draft preparation, writing \& editing: M.K supported by K.K., L.K., S.N., G.B. and H.S through review and feedback. All authors have read and agreed to the published version of the manuscript.

Funding: This work was conducted within the Food Pro-tec-ts project, which is carried out within the framework of the INTERREG V A program "Deutschland-Nederland" and is co-financed by the European Regional Development Fund (ERDF) and the Dutch Ministry of Economic Affairs and Climate Change, the Ministry of Economic Affairs, Innovation, Digitalisation and Energy of North Rhine-Westphalia and the provinces of Gelderland, Limburg and North Brabant. It is accompanied by the program management at the Euregio Rhein-Waal (project number 113071). The information and views set out in this publication are those of the authors and do not necessarily reflect the official opinion of the funders.

Institutional Review Board Statement: The study was conducted according to the Netherlands Code of Conduct for Research Integrity and approved by the Social Sciences Ethics Committee of Wageningen University on 1 July 2019.

Informed Consent Statement: All respondents gave consent for being interviewed and for the data being used for scientific analysis and reporting.

Data Availability Statement: Data are available upon request.

Acknowledgments: We would like to gratefully thank the SME owners as well as the respondents from innovation broker organisations and academic institutions, and the Euregio Rhein-Waal office who participated in our study. 
Conflicts of Interest: The authors declare no conflict of interest. The sponsors had no role in the design, execution, interpretation, and writing of the study and in the decision to publish the results.

\section{Appendix A}

Table A1. Overview of conducted interviews (DE stands for the German region, NL stands for the Dutch region).

\begin{tabular}{|c|c|c|c|c|c|c|}
\hline & $\begin{array}{l}\text { Interview Date } \\
\text { \& Language }\end{array}$ & $\begin{array}{c}\text { Innovation } \\
\text { Broker }\end{array}$ & University & SME & $\begin{array}{c}\text { Innovation Broker in } \\
\text { Some Way Linked to } \\
\text { Government }\end{array}$ & $\begin{array}{c}\text { Helicopter } \\
\text { View/Case-Specific } \\
\text { Interview } \\
\end{array}$ \\
\hline 1 & 31.03. English & $\mathrm{DE}$ & $\mathrm{DE}$ & & & Helicopter view \\
\hline 2 & 01.04. English & NL-DE & NL & & & Helicopter view \\
\hline 3 & 01.04. English & NL & & & $x$ & Helicopter view \\
\hline 4 & 03.04. English & $\mathrm{DE}$ & & & & Helicopter view \\
\hline 5 & 03.04. English & $\mathrm{DE}$ & & & $x$ & Case-specific interview \\
\hline 6 & 06.04. English & NL & & & $x$ & Case-specific interview \\
\hline 7 & 07.04. German & $\mathrm{DE}$ & $\mathrm{DE}$ & & & Case-specific interview \\
\hline 8 & 10.04. English & & & NL & & Case-specific interview \\
\hline 9 & 14.04. English & DE-NL & & & $x$ & Helicopter view \\
\hline 10 & 15.04. English & & & NL & & Case-specific interview \\
\hline 11 & 16.04. English & & & NL & & Case-specific interview \\
\hline 12 & 17.04. German & NL & NL & & & Case-specific interview \\
\hline 13 & 22.04 English & NL & & & & Helicopter view \\
\hline 14 & 28.04. English & & & NL & & Case-specific interview \\
\hline 15 & 04.05 German & $\mathrm{DE}$ & & & $x$ & Helicopter view \\
\hline 16 & 15.05. German & $\mathrm{DE}$ & & & $x$ & Helicopter view \\
\hline 17 & 25.05. German & $\mathrm{DE}$ & & & & Helicopter view \\
\hline 18 & 29.05. German & & & $\mathrm{DE}$ & & Case-specific interview \\
\hline 19 & 08.06. German & & & $\mathrm{DE}$ & & Case-specific interview \\
\hline \multicolumn{2}{|c|}{$\begin{array}{l}\text { Total number of } \\
\text { respondents }\end{array}$} & & & & & \\
\hline \multirow{3}{*}{\multicolumn{2}{|c|}{$\begin{array}{c}\text { NL respondents: } 8 \\
\text { DE respondents: } 9 \\
\text { Cross-border: } 2\end{array}$}} & 13 & 4 & 6 & 6 & 9 vs. 10 \\
\hline & & & & & & \\
\hline & & & & & & \\
\hline
\end{tabular}

\section{References}

1. Noferini, A.; Berzi, M.; Camonita, F.; Durà, A. Cross-Border Cooperation in the EU: Euroregions amid Multilevel Governance and Re-Territorialization. Eur. Plan. Stud. 2020, 28, 35-56. [CrossRef]

2. Interreg Europe-30 Stories I Interreg Europe. 2020. Available online: https:/ / www.interregeurope.eu/30stories/ (accessed on 12 October 2020).

3. Lundquist, K.J.; Trippl, M. Distance, Proximity and Types of Cross-Border Innovation Systems: A Conceptual Analysis. Reg. Stud. 2013, 47, 450-460. [CrossRef]

4. Lundquist, K.J.; Trippl, M. Towards Cross-Border Innovation Spaces. A Theoretical Analysis and Empirical Comparison of the Öresund Region and the Centrope Area; Institut für Regional- und Umweltwirtschaft, WU Vienna University of Economics and Business: Vienna, Austria, 2009.

5. Coenen, L.; På Vestlandet, H.; Moodysson, J.; Asheim, B. The Role of Proximities for Knowledge Dynamics in a Cross-Border Region: Biotechnology in Øresund. In Proceedings of the DRUID Summer Conference 2003, Copenhagen, Denmark, 12-13 June 2003.

6. Asheim, B.; Smith, H.L.; Oughton, C. Regional Innovation Systems: Theory, Empirics and Policy. Reg. Stud. 2011, 45, 875-891. [CrossRef]

7. Boschma, R.A. Proximity and Innovation: A Critical Assessment. Reg. Stud. 2005, 39, 61-74. [CrossRef]

8. Sternberg, R. Entrepreneurship, Proximity and Regional Innovation Systems. Tijdschr. Econ. Soc. Geogr. 2007, 98, 652-666. [CrossRef]

9. Asheim, B.; Gertler, M.S. The Geography of Innovation: Regional Innovation Systems; Fagerberg, J., Mowery, D.C., Nelson, R.R., Eds.; Oxford University Press: Oxford, UK, 2005; pp. 291-317.

10. Torre, A.; Gilly, J.P. On the Analytical Dimension of Proximity Dynamics. Reg. Stud. 2000, 34, 169-180. [CrossRef]

11. Granovetter, M. Economic Action and Social Structure: The Problem of Embeddedness'. Am. J. Sociol. 1985, 91, 481-510. [CrossRef] 
12. Moodysson, J.; Jonsson, O. Knowledge Collaboration and Proximity: The Spatial Organization of Biotech Innovation Projects. Eur. Urban Reg. Stud. 2007, 14, 115-131. [CrossRef]

13. Trippl, M. Developing Cross-Border Regional Innovation Systems: Key Factors and Challenges. Tijdschr. Econ. Soc. Geogr. 2010, 101, 150-160. [CrossRef]

14. Sohn, C. Modelling Cross-Border Integration: The Role of Borders as a Resource. Geopolitics 2014, 19, 587-608. [CrossRef]

15. Durand, F. Theoretical Framework of the Cross-Border Space Production-The Case of the Eurometropolis Lille-Kortrijk-Tournai. J. Borderl. Stud. 2015, 30, 309-328. [CrossRef]

16. Kraeger, P.; Pospíšil, M.; Howard, D.B.; Freise, M.; Sacco, J.; Chan, K.; Pospíšil, M.; Freise, M.; Lee, S.-E.; Howard, D.B.; et al. Hybridity/Hybridization. In International Encyclopedia of Civil Society; Springer: Cham, Switzerland, 2010; pp. 839-842. [CrossRef]

17. Lundvall, B.-Å. Scope, Style, and Theme of Research on Knowledge and Learning Societies. J. Knowl. Econ. 2010, 1, 18-23. [CrossRef]

18. Sohn, C. The Border as a Resource in the Global Urban Space: A Contribution to the Cross-Border Metropolis Hypothesis. Int. J. Urban Reg. Res. 2014, 38, 1697-1711. [CrossRef]

19. Rago, S.; Venturi, P. Hybridization as Systemic Innovation: Italian Social Enterprise on the Move. In Proceedings of the EMES International Conference on Social Enterprise-Helsinki, Helsinki, Finland, 1-3 September 2015.

20. Newman, D. On Borders and Power: A Theoretical Framework. J. Borderl. Stud. 2003, 18, 13-25. [CrossRef]

21. de Noronha Vaz, T.; Viaene, J.; Wigier, M. Innovation in Small Firms and Dynamics of Local Development; Scholar: Warszawa, Poland, 2004.

22. Narula, R. R\&D Collaboration by SMEs: New Opportunities and Limitations in the Face of Globalisation. Technovation 2004, 24, 153-161.

23. Nooteboom, B. Innovation and Diffusion in Small Firms-Theory and Evidence. Small Bus. Econ. 1994, 6, 327-347. [CrossRef]

24. Batterink, M.H.; Wubben, E.F.M.; Klerkx, L.; Omta, S.W.F. (Onno). Orchestrating Innovation Networks: The Case of Innovation Brokers in the Agri-Food Sector. Entrep. Reg. Dev. 2010, 22, 47-76. [CrossRef]

25. Kauffeld-Monz, M.; Fritsch, M. Who Are the Knowledge Brokers in Regional Systems of Innovation? A Multi-Actor Network Analysis. Reg. Stud. 2013, 47, 669-685. [CrossRef]

26. Gunasekara, C. The Generative and Developmental Roles of Universities in Regional Innovation Systems. Sci. Public Policy 2006, 33, 137-150. [CrossRef]

27. Howells, J. Intermediation and the Role of Intermediaries in Innovation. Res. Policy 2006, 35, 715-728. [CrossRef]

28. Winch, G.M.; Courtney, R. The Organization of Innovation Brokers: An International Review. Technol. Anal. Strateg. Manag. 2007, 19, 747-763. [CrossRef]

29. Barney, J.B.; Clark, D.N. Resource-Based Theory: Creating and Sustaining Competitive Advantage-Ghent University Library; Oxford University Press: Oxford, UK, 2007.

30. Tödtling, F.; Lengauer, L.; Höglinger, C. Knowledge Sourcing and Innovation in "Thick" and "Thin" Regional Innovation Systems-Comparing ICT Firms in Two Austrian Regions. Eur. Plan. Stud. 2011, 19, 1245-1276. [CrossRef]

31. van den Broek, J.; Smulders, H. Institutional Hindrances in Cross-Border Regional Innovation Systems. Reg. Stud. Reg. Sci. 2015, 2, 116-122. [CrossRef]

32. van den Broek, J. Agency and Institutions in the Construction of Cross-Border Innovation Spaces. Ph.D. Thesis, Radboud University Nijmegen, Nijmegen, The Netherlands, 2018.

33. van den Broek, J.; Benneworth, P.; Rutten, R. Institutionalization of Cross-Border Regional Innovation Systems: The Role of University Institutional Entrepreneurs. Reg. Stud. Reg. Sci. 2019, 6, 55-69. [CrossRef]

34. McKelvey, M. Firms Navigating through Innovation Spaces: A Conceptualization of How Firms Search and Perceive Technological, Market and Productive Opportunities Globally. J. Evol. Econ. 2016, 26, 785-802. [CrossRef]

35. Caccamo, M. Leveraging Innovation Spaces to Foster Collaborative Innovation. Creat. Innov. Manag. 2020, 29, 178-191. [CrossRef]

36. Klatt, M.; Herrmann, H. Half Empty or Half Full? Over 30 Years of Regional Cross-Border Cooperation Within the EU: Experiences at the Dutch-German and Danish-German Border. J. Borderl. Stud. 2011, 26, 65-87. [CrossRef]

37. Malerba, F. Sectoral Systems of Innovation and Production. Res. Policy 2002, 31, 247-264. [CrossRef]

38. Lundvall, B.-Å.; Johnson, B.; Andersen, E.S.; Dalum, B.; Lundvall, B.-Å.; Johnson, B.; Andersen, E.; Dalum, B. National Systems of Production, Innovation and Competence Building. Res. Policy 2002, 31, 213-231. [CrossRef]

39. Cooke, P.; Gomez Uranga, M.; Etxebarria, G.; Cooke, P.; Gomez Uranga, M.; Etxebarria, G. Regional Innovation Systems: Institutional and Organisational Dimensions. Res. Policy 1997, 26, 475-491. [CrossRef]

40. Nelson, R.R. National Innovation Systems: A Comparative Analysis; Oxford University Press: Oxford, UK, 1993.

41. Edquist, C.; Johnson, B. Systems of Innovation; Edquist, C., Ed.; Routledge: London, UK, 1997. [CrossRef]

42. Gibbons, M.; Limoges, C.; Nowotny, H.; Schwartzman, S.; Scott, P.; Trow, M. The New Production of Knowledge: The Dynamics of Science and Research in Contemporary Societies; Sage: Thousand Oaks, CA, USA, 1994.

43. Knickel, K.; Brunori, G.; Rand, S.; Proost, J. Towards a Better Conceptual Framework for Innovation Processes in Agriculture and Rural Development: From Linear Models to Systemic Approaches. J. Agric. Educ. Ext. 2009, 15, 131-146. [CrossRef]

44. Lundvall, B.-Å. National Systems of Innovation: Towards a Theory of Innovation and Interactive Learning; Pinter Publishers: London, $\mathrm{UK}, 1992$. 
45. Klerkx, L.; Seuneke, P.; de Wolf, P.; Rossing, W.A.H. Replication and Translation of Co-Innovation: The Influence of Institutional Context in Large International Participatory Research Projects. Land Use Policy 2017, 61, 276-292. [CrossRef]

46. Ma, X.-F.; Kaldenbach, M.; Katzy, B. Cross-Border Innovation Intermediaries-Matchmaking across Institutional Contexts. Technol. Anal. Strateg. Manag. 2014, 26, 703-716. [CrossRef]

47. Tödtling, F.; Trippl, M.; Tödtling, F.; Trippl, M. One Size Fits All? Towards a Differentiated Regional Innovation Policy Approach. Res. Policy 2005, 34, 1203-1219. [CrossRef]

48. Schrempf, B.; Kaplan, D.; Schroeder, D. National, Regional, and Sectoral Systems of Innovation-An Overview Deliverable 2.2; Report for FP7 Project Progress. 2013. Available online: https://www.progressproject.eu/wp-content/uploads/2013/12/ Progress_D2.2_final.pdf (accessed on 5 September 2020).

49. Zawdie, G. Special Issue: Knowledge Exchange and the Third Mission of Universities. Ind. High. Educ. 2010, 24, 151-155. [CrossRef]

50. Nakwa, K.; Zawdie, G. The "third Mission" and "Triple Helix Mission" of Universities as Evolutionary Processes in the Development of the Network of Knowledge Production: Reflections on SME Experiences in Thailand. Sci. Public Policy 2016, 43, 622-629. [CrossRef]

51. Frondizi, R.; Fantauzzi, C.; Colasanti, N.; Fiorani, G. The Evaluation of Universities' Third Mission and Intellectual Capital: Theoretical Analysis and Application to Italy. Sustainability 2019, 11, 3455. [CrossRef]

52. Klerkx, L.; Guimón, J. Attracting Foreign R\&D through International Centres of Excellence: Early Experiences from Chile. Sci. Public Policy 2017, 44, 763-774. [CrossRef]

53. Falah, G.; Newman, D. The Spatial Manifestation of Threat: Israelis and Palestinians Seek a "good" Border. Polit. Geogr. 1995, 14, 689-706. [CrossRef]

54. Williams, J. Territorial Borders, International Ethics and Geography: Do Good Fences Still Make Good Neighbours? Geopolitics 2003, 8, 25-46. [CrossRef]

55. Gertler, M.S. Tacit Knowledge and the Economic Geography of Context, or the Undefinable Tacitness of Being (There). J. Econ. Geogr. 2003, 3, 75-99. [CrossRef]

56. Hoekman, J.; Frenken, K.; van Oort, F. The Geography of Collaborative Knowledge Production in Europe. Ann. Reg. Sci. 2009, 43, 721-738. [CrossRef]

57. Cooke, P.; Heidenreich, M.; Braczyk, H.-J. Regional Innovation Systems, 2nd ed.; Routledge: London, UK; New York, NY, USA, 2004.

58. Lundquist, K.J.; Winther, L. The Interspace between Denmark and Sweden: The Industrial Dynamics of the Öresund Cross-Border Region. Geogr. Tidsskr. 2006, 106, 115-129. [CrossRef]

59. Nooteboom, B.; Van Haverbeke, W.; Duysters, G.; Gilsing, V.; van den Oord, A.; Nooteboom, B.; Van Haverbeke, W.; Duysters, G.; Gilsing, V.; van den Oord, A. Optimal Cognitive Distance and Absorptive Capacity. Res. Policy 2007, 36, 1016-1034. [CrossRef]

60. Nooteboom, B. Learning and Innovation in Organizations and Economies; Oxford University Press: Oxford, UK, 2001. [CrossRef]

61. Frenken, K.; Van Oort, F.; Verburg, T. Related Variety, Unrelated Variety and Regional Economic Growth. Reg. Stud. 2007, 41, 685-697. [CrossRef]

62. Smith, K. Economic Infrastructures and Innovation Systems. In Systems of Innovation. Technologies, Institutions and Organizations; Edquist, C., Ed.; Pinter: London, UK; Washington, DC, USA, 1997; pp. 86-106.

63. Klerkx, L.; Leeuwis, C. Establishment and Embedding of Innovation Brokers at Different Innovation System Levels: Insights from the Dutch Agricultural Sector. Technol. Forecast. Soc. Chang. 2009, 76, 849-860. [CrossRef]

64. Koschatzky, K. A River Is a River-Cross-Border Networking between Baden and Alsace. Eur. Plan. Stud. 2000, 8, 429-449. [CrossRef]

65. Hermans, F.; Klerkx, L.; Roep, D. Structural Conditions for Collaboration and Learning in Innovation Networks: Using an Innovation System Performance Lens to Analyse Agricultural Knowledge Systems. J. Agric. Educ. Ext. 2015, 21, 35-54. [CrossRef]

66. Doloreux, D. What We Should Know about Regional Systems of Innovation. Technol. Soc. 2002, 24, 243-263. [CrossRef]

67. Knickel, M.; Knickel, K.; Galli, F.; Maye, D.; Wiskerke, J.S.C. Towards a Reflexive Framework for Fostering Co-Learning and Improvement of Transdisciplinary Collaboration. Sustainability 2019, 11, 6602. [CrossRef]

68. Topaloglou, L.; Kallioras, D.; Manetos, P.; Petrakos, G. A Border Regions Typology in the Enlarged European Union. J. Borderl. Stud. 2005, 20, 67-89. [CrossRef]

69. Perkmann, M. Cross-Border Regions in Europe: Significance and Drivers of Regional Cross-Border Co-Operation. Eur. Urban Reg. Stud. 2003, 10, 153-171. [CrossRef]

70. Eurostat. Statistics Explained. Available online: https://ec.europa.eu/eurostat/statistics-explained/index.php/Main_Page (accessed on 6 December 2020).

71. Eurostat Regional Yearbook. Available online: https:/ / ec.europa.eu/eurostat/documents/3217494/11348978/KS-HA-20-001 -EN-N.pdf/f1ac43ea-cb38-3ffb-ce1f-f0255876b670 (accessed on 6 December 2020).

72. PricewaterhouseCoopers. Sozioökonomische Und SWOT-Analyse Für Das EU-Programm "Europäische Territoriale Zusammenarbeit." Niederlande, Nordrhein-Westfalen Und Niedersachsen Förderperiode 2007 Bis 2013 Teil 1: Sozioökonomische Und SWOT-Analyse; PricewaterhouseCoopers: London, UK, 2013.

73. de Ruiter, H.; Brinkman, J. Euregio Rijn-Waal in Cijfers | Euregio Rhein-Waal in Zahlen; Euregio Rijn-Waal: Kleve, Germany, 2017. 
74. Creswell, J.W. Qualitative Inquiry and Research Design: Choosing among Five Approaches, 3rd ed.; SAGE Publications Inc.: Thousand Oaks, CA, USA, 2013.

75. Miles, M.B.; Huberman, A.M. Qualitative Data Analysis: An Expanded Sourcebook, 2nd ed.; Sage Publications: Thousand Oaks, CA, USA, 1994.

76. Yin, R.K. Qualitative Research from Start to Finish; The Guilford Press: New York, NY, USA, 2011.

77. Miles, M.B.; Huberman, A.M.; Saldaña, J. Qualitative Data Analysis: A Methods Sourcebook, 3rd ed.; Sage: Thousand Oaks, CA, USA, 2014.

78. Charmaz, K. Grounded Theory Methods in Social Justice Research. The SAGE Handbook of Qualitative Research, 4th ed.; Denzin, N.K., Lincoln, Y.S., Eds.; Sage: Thousand Oaks, CA, USA, 2011.

79. Patton, M.Q. Qualitative Research E Evaluation Methods: Integrating Theory and Practice, 4th ed.; SAGE Publications Inc.: Thousand Oaks, CA, USA, 2015.

80. Glaser, B.G.; Strauss, A.L. Discovery of Grounded Theory: Strategies for Qualitative Research, 1st ed.; Routledge: London, UK, 1999.

81. Saldana, J. The Coding Manual for Qualitative Researchers, 2nd ed.; SAGE Publications, Inc.: Thousand Oaks, CA, USA, 2013.

82. Klerkx, L.; Hall, A.; Leeuwis, C. Strengthening Agricultural Innovation Capacity: Are Innovation Brokers the Answer? Int. J. Agric. Resour. Gov. Ecol. 2009, 8, 409-438. [CrossRef]

83. Fisher, C. Knowledge Brokering and Intermediary Concepts Analysis of an E-Discussion on the Knowledge Brokers' Forum; IDS Knowledge Services: Brighton, UK, 2011. Available online: https://assets.publishing.service.gov.uk/media/57a08ae2e5274a31e0000822 /Knowledge_Brokering_and_Intermediary_concepts_discussion_Summary.pdf (accessed on 18 September 2020).

84. Apa, R.; De Marchi, V.; Grandinetti, R.; Sedita, S.R. University-SME Collaboration and Innovation Performance: The Role of Informal Relationships and Absorptive Capacity. J. Technol. Transf. 2020, 1-28. [CrossRef]

85. Gaisch, M.; Noemeyer, D.; Aichinger, R. Third Mission Activities at Austrian Universities of Applied Sciences: Results from an Expert Survey. Publications 2019, 7, 57. [CrossRef]

86. Etzkowitz, H.; Leydesdorff, L. The Triple Helix-University-Industry-Government Relations: A Laboratory for Knowledge Based Economic Development. EASST Rev. 1995, 14, 14-19.

87. Etzkowitz, H.; Leydesdorff, L. The Dynamics of Innovation: From National Systems and "Mode 2" to a Triple Helix of UniversityIndustry-Government Relations. Res. Policy 2000, 29, 109-123. [CrossRef]

88. Hanna, V.; Walsh, K. Interfirm Cooperation among Small Manufacturing Firms. Int. Small Bus. J. Res. Entrep. 2008, 26, $299-321$. [CrossRef] 